\title{
Special Education Policy and EFL in Japan
}

\section{Davey Young \\ Sophia University}

\section{Reference Data}

Young, D. (2021). Special education policy and EFL in Japan. In P. Clements, R. Derrah, \& P. Ferguson (Eds.), Communities of teachers \& learners. JALT. https://doi.org/10.37546/ JALTPCP2020-05

Inclusive education is becoming increasingly important thanks in large part to international policy guidance by the United Nations, though country-specific policy often lags behind global policy guidance by the United Nations, though country-specific policy often lags behind global
standards. An overview of the history of inclusive education in Japan will be provided to help contextualize how different policies for compulsory and postsecondary education take different approaches to meet international standards as outlined in the UN's Convention on the Rights of Persons with Disabilities. Key policies that included provisions for inclusive education in Japan are then analyzed and discussed. Finally, additional considerations will be provided for how English language teachers can teach inclusively and help safeguard quality language education as a human right for all students.

インクルーシブ教育は、国別の政策が国際水準にたいして後れをとつていることが多いものの、国連主導の国際的な政策 指針のおかげで、ますます重要性を増している。本稿は、義務教育と中等教育後の学習機関の異なる政策が、国連で採択され た「障害者権利条約」にある国際水準を満たすべくいかに異なるアプローチを取りうるのかを考察するために、日本における インクルーシブ教育の歴史を概観する。その後、日本におけるインクルーシブ教育に関する条項を含む重要な政策について 分析し検討する。最後に、英語教師が゙゙のようにしてインクルーシブ教育をおこない、すべての学生の人権として言語教育の 質を保証することができるかという点において補足的な検討を加える。

lthough language learning can present barriers to certain types of disability - (Kormos, 2017), language teachers are generally unprepared to teach in ways that help minimize or remove those barriers (Kormos \& Smith, 2012). The number of students with recognized disabilities (SWDs) is rising in both compulsory (Mithout,
2016) and postsecondary (JASSO, 2020a) education in Japan, and the United Nations (n.d.) has called for all member states to position education as a human right so that all people, including those with disabilities, can become fully active participants in society. It is therefore important that language teachers in Japan be aware of their legal and ethical obligations to teach SWDs.

\section{Defining Terms}

Special Education, Disability, and Specific Learning Difficulties

There has been a great deal of debate about what language should be used to talk about issues surrounding disability and persons with disabilities, and the term special education is viewed as problematic in a variety of contexts (Evans et al., 2017). However, due to frequent use of this term in the English language policy literature published by Japan's Ministry of Education, Culture, Sports, Science and Technology (MEXT), the term special education will be used in this paper when referring to a specific policy. Otherwise, the term disability will be used as it is evoked in the United Nations Convention on the Rights of Persons with Disabilities (CRPD) held in 2006. This document declines to concretely define disability, instead noting that it is an evolving concept that "results from the interaction between persons with impairments and attitudinal and environmental barriers that hinders their full and effective participation in society on an equal basis with others" (United Nations, n.d., p. 1). This dynamic view accords with the interactionist model of disability, which holds that "students' ability to function in an environment is an interaction of the environment, the person, and the person's impairment" (Evans et al., 2017, p. 77), and empowers practitioners to design learning environments that are more accommodating to an array of individuals and impairments.

Concerningly, however, the term disability is often associated with the medical model, which frames impairments as defects that can be treated or cured (Evans et al., 2017). This view encourages labeling and confining impairments to specific diagnoses. 
In reality, many learning disabilities overlap and lack clear distinction from a cognitive perspective (Kormos, 2017). Therefore, the present paper will use the term specific learning difficulty (SpLD) to refer to impairments that have a more direct relationship with language learning. SpLDs include dyslexia, dyspraxia, dysgraphia, autism spectrum disorder, ADHD, and social, emotional, and behavioral difficulties.

\section{Inclusive Education and Inclusive Practices}

While inclusive education now exists as an international concept, it can mean different things to different people in different contexts (Hunt, 2019). This is largely owing to how the concept developed as similar modes of practice in relatively isolated teaching lineages have converged and become more intertwined in recent years, beginning with the Salamanca Statement of 1994 (Hunt, 2019). Now that it has become a more international concept, there is some tension around how inclusive education is framed and implemented, especially from a policy perspective, for example, between international policy guidance and national policy, and between national policy and local implementation (Hunt, 2019)

This paper will use the definition of inclusive education provided in the CRPD General comment No. 4, as this particular policy has become "the de facto global development policy on inclusive education because it outlines the critical policy considerations and implementation guidelines for Inclusive Education for all UNCRPD signatory and ratifying countries" (Hunt, 2019, p. 116). This definition frames education as a human right for all people.

As notions of inclusive education are context-dependent, so can the realization of these notions in actual practice vary from context to context. To account for the range of such pedagogy, inclusive practices will be defined here as those principles and procedures that allow teachers to respond to individual differences between learners, but avoid possible marginalization that may result when students are treated differently (Florian \& Beaton, 2017)

\section{History of Inclusive Education in Japan}

As in many other countries, inclusive education in Japan grew out of special education, and its development can be divided into three phases that parallel corresponding periods of social welfare for persons with disabilities as framed by Japanese legal and political language (Heyer, 2015; Mithout, 2016).
From 1947 to 1980, "policies focused on guaranteeing the respect of basic human rights through a number of laws aimed at enforcing the right of every individual to lead a decent life" (Mithout, 2016, p. 167). In practice, however, welfare laws effectively segregated persons with disabilities from the rest of society by placing them in institutions like assisted living facilities and special schools (Mithout, 2016). Because the Education Law passed in 1947 failed to establish state-mandated special education, a number of teachers' associations and parents' organizations lobbied the government to create special education schools, which eventually occurred in 1956 with the enactment of the Special Education School Establishment Law (Heyer, 2015). This law guaranteed compulsory education through junior high school for children with physical disabilities in segregated special schools called you go gakkou; special schools for children with visual or auditory impairments existed prior to 1956 (Heyer, 2015). In 1974, the Tokyo government made education legally compulsory for students with a disability, and the national government followed suit in 1979, safeguarding compulsory education for students with mental disabilities for the first time (Watanabe et al., 2017). However, even the special schools designated for students with disabilities could legally refuse to enroll students if they deemed those students' needs to be too great to meet, a policy which tacitly permitted institutional exclusion of SWDs.

The 1980s and 1990s "were marked by a political willingness to support disabled people's autonomy and social participation, under the influence of ideas like 'normalization' and 'full equality,' especially as promoted by international organizations" (Mithout, 2016, p. 168). In this phase, more and more children with disabilities were admitted to traditional schools to study alongside their abled peers as the Japanese government followed the normalization principle, defined as "the creation of a society in which all people can lead ordinary lives in their communities, regardless of the presence of any disability" (Ministry of Health and Welfare, 1982, as cited in Heyer, 2015).

This principle informed revisions to various laws and policies regarding persons with disabilities, propelled in part by continued activism by the disability rights community that helped wider society accept the active participation of people with disabilities in their communities (Heyer, 2015). However, reforms in education often maintained clear segregation of learning environments for students with disabilities (Mithout, 2016). Such environments included special education classes [tokushu gakkyuu] and resource rooms [tsukyu] in compulsory public schools.

The 2000s saw a number of reforms in social welfare and education that helped remove some of the systems of oppression of people with disabilities in Japanese society and education (Heyer, 2015). Current policy and its implementation vary significantly 
between levels of education, but since the drafting of the CRPD in 2006, the quality of inclusive education in Japan has generally improved despite the continued use of special education classes and resource rooms (Heyer, 2015; Ree, 2015).

\section{International Policy on Inclusive Education}

The CRPD was a watershed moment in setting a universal standard for inclusive education (Hunt, 2019). It both improved upon the language of the Salamanca Statement of 1994, as well as garnered more and firmer commitments from the international community, and has subsequently shaped domestic policy in a number of countries, including Japan. The purpose of the CRPD was "to promote, protect and ensure the full and equal enjoyment of all human rights and fundamental freedoms by all persons with disabilities, and to promote respect for their inherent dignity" (United Nations, n.d., p. 4). The CRPD called for signatories to ratify the agreement by 2008, though Japan delayed until 2014, claiming that they needed time to make policy and legislative adjustments (Ree, 2015).

Article 24, Paragraph 2 of the CRPD is concerned with primary and secondary education and makes clear States Parties shall ensure that

(a) Persons with disabilities are not excluded from the general education system on the basis of disability, and that children with disabilities are not excluded from free and compulsory primary education, or from secondary education, on the basis of disability;

(b) Persons with disabilities can access an inclusive, quality and free primary education and secondary education on an equal basis with others in the communities in which they live;

(c) Reasonable accommodation of the individual's requirements is provided;

(d) Persons with disabilities receive the support required, within the general education system, to facilitate their effective education;

(e) Effective individualized support measures are provided in environments that maximize academic and social development, consistent with the goal of full inclusion. (United Nations, n.d., p. 17)

Article 24, Paragraph 5 pertains to higher education and states that signatories shall guarantee persons with disabilities are able to access general tertiary education, vocational training, adult education and lifelong learning without discrimination and on an equal basis with others. To this end, States Parties shall ensure that reasonable accommodation is provided to persons with disabilities. (United Nations, n.d., p. 18)

The term reasonable accommodation originated in the CRPD, where it is defined as necessary and appropriate modification and adjustments not imposing a disproportionate or undue burden, where needed in a particular case, to ensure to persons with disabilities the enjoyment or exercise on an equal basis with others of all human rights and fundamental freedoms. (United Nations, n.d., p. 4)

This term is also used in the English versions of key post-CRPD policy in Japan, though the Japanese language documents use the term gouri-teki hairyo (合理的配慮).

\section{Policy and Implementation of Inclusive Education in Primary and Secondary Education in Japan}

Article 4 of the 2006 Revision to the Basic Act on Education (教育基本法) declares that

[t]he people must be given equal opportunities to receive an education suited to their abilities, and must not be subjected to discrimination in education on account of race, creed, sex, social status, economic position, or family origin.

(2) The national and local governments shall provide the necessary educational support to ensure that persons with disabilities receive an adequate education in accordance with their level of disability.

(3) The national and local governments shall take measures to provide financial assistance to those who, in spite of their abilities, encounter difficulties in receiving education for economic reasons. (MEXT, n.d.)

The 2006 Revision to the Basic Act on Education shifted conceptually from special education [tokushu kyouiku] to special support education [tokubetsu shien kyouiku], and was "oriented toward educating autonomous individuals and offering families a free choice of school" (Mithout, 2016, p. 168). Students with disabilities now have three options: special schools, special classes within traditional schools, and attending regular classes in traditional schools. Enrollment in all three options has increased since the 2006 Revision to the Basic Act on Education, with "enrollment in regular classes up by 
50\% and enrollment in special classes up by 150\% between 2005 and 2012" (Mithout, 2016, p. 172). Taking a closer look at the numbers, Mithout (2016) notes that "two trends can be distinguished: (i) a growing enrollment of children with autism into mainstream schools and (ii) the development, inside mainstream schools, of a support system for children with difficulties who were already attending regular education" (p. 174).

The inclusion of the term "in accordance with their level of disability" in the policy is problematic, however, as it gives school administrators a great deal of leeway to decide how levels are defined (Ree, 2015). The increase in numbers as reported by Mithout (2016) is also problematized by MEXT's classification of emotional disorders, which gives teachers and school administrators the freedom to label students who exhibit violence as special needs students and, in theory, segregate them from other students by placing them in special classes (Mithout, 2016; Ree, 2015). Principals make the final decision about where students with disabilities are placed in their schools, and students' families have no legal recourse to appeal a placement decision; in combination, these policies allow for the perpetuation of exclusionary practices, for example, intra-school labeling and segregating of students with disabilities in Japanese primary and secondary education that do not accord with the CRPD's broader vision for inclusive education (Ree, 2015).

In 2012, nearly $80 \%$ of students with disabilities attended traditional schools for compulsory education (grades 1-9), though only $24 \%$ joined regular classes for grades 1-6, and 1\% integrated into grades 7-9 (Ree, 2015). The dramatic decrease in integration for grades 7-9 is likely because students can choose a new option, pending administrative approval, upon entering junior high school. However, it is not known how many students are choosing to leave regular classes, how many are being segregated by administrative decree, and in either case, what factors may lead to such a decision.

It is also worth bearing in mind that integration or mainstreaming of students with disabilities does not automatically constitute inclusion (Hunt, 2019). In Japan specifically, there are a number of concerns regarding the inclusion of children with disabilities who have been integrated into traditional schools. Some schools, for instance, have struggled to provide adequate resources such as trained staff and classrooms (Mithout, 2016). In addition, teacher training in Japan is not fully preparing teachers to teach SWDs in their regular classes (Forlin, 2013). Mithout (2016) also identified through her fieldwork that such students can be socially excluded by their peers, are bullied more often by their peers, and may even be pressured by the school to move to a special support class from the regular class.

Despite these criticisms and concerns, there are reasons to believe that the situation is improving. Special schools now have a wider remit, playing new roles "as local centers of expertise, working in close collaboration with mainstream schools to provide support, advice, and training to regular teachers who have disabled children in their classrooms" (Mithout, 2016, p. 170). Additionally, some municipalities have made efforts to meet the CRPD's standards for reasonable accommodations and done so with assistance from MEXT.

In 2013, MEXT created the Developing Inclusive Education System in response to the CRPD and selected 65 local municipalities and schools to pilot it. Yamaga City in Kumamoto was one such place and adopted a three-pronged approach to meet the needs of the municipality: (a) school clusters of junior high schools for resource-sharing, (b) incremental support for providing reasonable accommodations, and (c) incremental case meetings between classroom teachers, school staff, special needs educators, and reasonable accommodation promotion staff (Furuta \& Osugi, 2016). Critically, and despite MEXT's involvement, this model was created to follow the CRPD, not the 2006 Revision to the Basic Act on Education. This suggests that at least some local municipalities favor an international view of inclusive education instead of or in addition to a national one. Finally, the implementation of the Developing Inclusive Education System supports two arguments on inclusive education policy from Hunt (2019): firstly, it is crucial to have buy-in from people on the ground-policy alone is not enough; secondly, the implementation of international policy must bend itself to the needs of the local environment if it is to be effective.

\section{Policy and Implementation of Inclusive Education in Postsecondary Education in Japan}

There is currently no equivalent of the 2006 Revision to the Basic Act on Education for higher education in Japan. Instead, higher education institutes (HEIs) must look to the Act on the Elimination of Disability Discrimination (AEDD), a policy document that is primarily concerned with eliminating disability discrimination in the workplace and within government agencies. Though there are provisions aimed at higher education in the AEDD, they do not explicitly address issues related to disability in education. Rather than position education as a human right, the AEDD instead frames education as a commodity, with HEls positioned as producers and students as consumers. Guarantees of financial support for SWDs are also absent from the AEDD, which can present financial barriers to students with disabilities seeking tertiary education that they did not encounter in their compulsory education. The protections for students with disabilities in postsecondary contexts do still rest on the notion of reasonable accommodation, though the term is not clearly defined in the AEDD (Boeltzig-Brown, 2017). 
Until the AEDD took effect on April 1, 2016, no HEls were legally required to provide reasonable accommodations of any kind. The previous academic year, in 2015, 0.68\% of all students in higher education in Japan reported having a disability (JASSO, 2020a). That same year, $3.58 \%$ of students in primary and secondary Japanese education had a disability (Isogai, 2017). This difference suggests at least two things: firstly, some students with disabilities are encountering barriers to accessing higher education that their abled peers are not; secondly, some unknown number of students with disabilities are not self-identifying when they enter university. This is a critical difference between primary and secondary and postsecondary contexts. In the former, students are required by law to disclose their disability when entering schools, ostensibly in order to receive support from the school, though historically this has been used as a way to exclude these students from regular schooling (Heyer, 2015; Watanabe et al., 2017). In higher education, however, the policy is one of selective inclusion: if students do not want to disclose their disability, they do not have to. This approach certainly has benefits in terms of privacy protection but makes it more difficult for students with disabilities to receive accommodations from the school. More importantly, while the AEDD mandates that public HEIs provide reasonable accommodations, private ones are merely encouraged to do so; in other words, private HEls have no legal responsibility to include SWDs (Kondo et al., 2015).

Considering the lack of clear policy provisions for SWDs in Japanese HEIs, it should come as no surprise that there is a great diversity of support systems and differences in quality to providing reasonable accommodations across the postsecondary educational landscape in Japan. The specifics of in-class and out-of-class accommodations also vary wildly, with some schools, for instance, providing services like notetakers, sign language interpreters, the conversion of classroom materials into braille, counseling services, and student helpers, among others; some schools employ full-time support staff, some parttime, some outsourced, and most with some combination therein (JASSO, 2020b). As the Japan Student Services Organization (JASSO) does not collect data on teaching pedagogy, it is difficult to know how many and to what degree teachers in HEls use inclusive practices in their classroom instruction.

\section{SpLDs and Language Learning}

Language learning can present both cognitive and affective barriers to students with specific learning difficulties such as dyslexia and ADHD. Compared to their abled peers, "language learners with SpLDs show significant differences in their working memory and phonological short-term memory capacity," both of which are "important predictors of success in language learning" (Kormos, 2017, p. 47). Depending on the exact nature of the SpLD and other factors in the learner profile, students with SpLDs may have difficulty processing input (written and/or spoken), automatization and creation of long-term memory, and producing output (Kormos, 2017). In some cases, students may encounter barriers related to an SpLD in their L2, but not in their L1. English's opaque orthography and irregular spelling conventions, for instance, may present barriers to students who have a phonological processing deficit, whereas the more transparent Japanese orthographies present different difficulties (Tanahashi, 2010).

Anxiety can influence learning and performance across cognitive domains and can do so with particular acuity in L2 learning due to the feelings of uncertainty and threats to self-esteem and self-concept that language learning can evoke. Foreign language anxiety (FLA) is a type of situation-specific anxiety that was first proposed in the 1980s and has been found to correlate with poor attainment of speaking, writing, and grammatical understanding in a foreign language (Kormos, 2017). While all language learners may feel anxiety from time to time, "it has been demonstrated that students with SpLDs tend to demonstrate higher levels of FLA than their peers with no SpLDs" (Kormos, 2017, p. 77). This has been found to be true at almost all stages of $\mathrm{L} 2$ learning, leading to a "vicious circle for these students, as they might already face challenges due to their potentially lower working memory and phonological short-term memory capacity that can hinder the processing of new L2 knowledge" (Kormos, 2017, p. 79). This vicious circle can turn into a spiral, negatively affecting a student's motivation to learn the language, and potentially lowering their sense of self-worth beyond their experience of language learning (Kormos, 2017).

Bearing in mind that the increasing number of students receiving special support in primary and secondary schools "has coincided with a period of increased recognition of 'developmental disorders' (hattatsu shougai), including attention deficit, hyperactivity, and learning disorders" (Mithout, 2016, p. 171), as well as that these same learning difficulties may go unnoticed in postsecondary classrooms if students are undiagnosed or have not disclosed their disability, teachers would do well to assume the presence of SpLDs in any given classroom.

\section{Inclusive Language Education in Japan}

Language teachers generally lack training in special education (Kormos \& Smith, 2012), and training in special education or inclusive practices is a very uncommon feature of MA TESOL programs worldwide (Stapleton \& Shao, 2018). In one study, Hale and 
Ono (2019) found that Japanese English language teachers in junior and senior high schools lacked both training and confidence in accommodating students with SpLDs in their classrooms, a finding which accords with general education teachers in Japan as determined by the Forlin (2013) study cited above. There is a lack of similar research for English language teachers in higher education in Japan.

\section{Principles of Inclusive Practices for Language Teachers}

The guidelines below have been modified from Grace and Gravestock (2009) and Smith (2018), and can help language teachers at all levels create inclusive learning environments that minimize barriers for students with SpLDs and other forms of disability in line with the CRPD's definition of reasonable accommodation:

- Differentiate learning materials and tasks

- Use multisensory and multimodal materials and tasks

- Use visual organizers

- Use appropriate fonts and formatting in materials (e.g., sans serif fonts and left justification)

- Routinize instructions and task structures

- Help learners develop learning strategies and metacognition

- Allow collaborative pair and group work

- Provide resources for out of class support

- Minimize distractions in the learning environment

- Arrange the classroom with physical and sensory impairments in mind

As there is also some overlap between principles of communicative language teaching and inclusive practices (Smith, 2018), language teachers would do well to take a communicative approach to provide more barrier-free instruction compared to other approaches to language teaching.

\section{Conclusion}

While Japanese schools at all levels have, in aggregate, become more inclusive in recent decades, exclusionary practices such as the segregation of students with disabilities or the absence of accessible learning environments can and do persist in many schools and higher education institutions. Examples have been documented by both outside researchers (Boeltzig-Brown, 2017; Heyer, 2015; Mithout, 2016; Ree, 2015) and JASSO (JASSO, 2020b). Unfortunately, a full accounting of these practices is beyond the scope of the present paper. However, having a basic understanding of these exclusionary practices provides invaluable context about what barriers SWDs may face at different stages of their education, and this knowledge can inform how teachers design and deliver inclusive courses and lessons. Furthermore, a more informed body of teachers across contexts within Japan can help create a critical mass of inclusively minded teachers to drive systemic change. To this end, we should be mindful of the barriers our students face both in and out of the classroom, and work actively to help remove those barriers by following principles of inclusive practices and advocating for all students' basic human right to education.

\section{Bio Data}

Davey Young is a lecturer in the Department of English Studies at Sophia University and a doctoral student in the Graduate School of Asia Pacific Studies at Waseda University. His current research is focused on the preparedness of postsecondary English language teachers to teach students with disabilities. dyoung@sophia.ac.jp

\section{References}

Boeltzig-Brown, H. (2017). Disability and career service provision for students with disabilities at institutions of higher education in Japan: An overview of key legislation, policies, and practices. Journal of Postsecondary Education and Disability, 30(1), 61-81. https://eric.ed.gov/?id=EJ1144616

Evans, N., Broido, E. M., Brown, K. R., \& Wilke, A. K. (2017). Disability in higher education: A social justice approach. Jossey-Bass.

Florian, L. \& Beaton, M. (2017). Inclusive pedagogy in action: Getting it right for every child. International Journal of Inclusive Education, 22(8), 870-884. https://doi.org/10.1080/13603116.20 17.1412513

Forlin, C. (2013). Issues of inclusive education in the 21st century. Journal of Learning Science, 6 , 67-81. http://doi.org/10.15027/35243

Furuta, H., \& Osugi, N. (2016). Developing an inclusive education system in Japan: The case of Yamaga City, Kumamoto. Bulletin of the Faculty of Education, Kumamoto University, 65, 139-144. https://core.ac.uk/download/pdf/75886119.pdf

Grace, S., \& Gravestock, P. (2009). Inclusion \& diversity: Meeting the needs of all students. Routledge. 
Hale, C. C., \& Ono, S. (2019). Second language learning for students with special needs: Perceptions of Japanese secondary school teachers. Accents Asia, 11(2), 78-83. http://www.issues.accentsasia. org/issues/11-2/hale_ono.pdf

Heyer, K. (2015). Rights enabled: The disability revolution, from the US, to Germany and Japan, to the United Nations. University of Michigan Press.

Hunt, P. F. (2019). Inclusive education as global development policy. In M. J. Schuelka, C. J. Johnstone, G. Thomas, \& A. J. Artiles (Eds.), The SAGE handbook of inclusion and diversity in education (pp. 116-129). SAGE.

Isogai, K. (2017). Recent developments in Japan's special needs education: Promoting an inclusive education system. NISE Bulletin, 16, 28-32.

JASSO. (2020a). https://www.jasso.go.jp/gakusei/tokubetsu_shien/chosa_kenkyu/chosa/index.html JASSO. (2020b). https://www.jasso.go.jp/gakusei/tokubetsu_shien/chosa_kenkyu/chosa/_icsFiles/ afieldfile/2020/04/02/report2019_0401.pdf

Kondo, T., Takahashi, T., \& Shirasawa, M. (2015). Recent progress and future challenges in disability student services in Japan. Journal of Postsecondary Education and Disability, 28(4), 421-431. https://eric.ed.gov/?id=EJ1093579

Kormos, J. (2017). The second language learning processes of students with specific learning difficulties. Routledge.

Kormos, J., \& Smith, A. M. (2012). Teaching languages to students with specific learning differences. Multilingual Matters.

MEXT. (n.d.). Basic act on education. https://www.mext.go.jp/en/policy/education/lawandplan/ title01/detail01/1373798.htm

Mithout, A. (2016). Children with disabilities in the Japanese school system: A path toward social integration? Contemporary Japan, 28(2), 165-184. https://doi.org/10.1515/cj-2016-0009

Ree, S. (2015). Inclusive education in Japan and Australia: A comparative legislative and policy analysis. Bulletin of Den-en Chofu University, 10, 51-68. http://id.nii.ac.jp/1123/00000550/

Smith, A. M. (2018). Inclusive practices in English Language Teaching. Oxford University Press. https://elt.oup.com/feature/global/expert/inclusive?cc=jp\&selLanguage=ja

Stapleton, P., \& Shao, Q. (2018). A worldwide survey of MATESOL programs in 2014 Patterns and perspectives. Language Teaching Research, 22(1), 10-28. https://doi. org/10.1177/1362168816659681

Tanahashi, S. (2010). Dyslexia in Japan: Clues for better English language learning strategies. 文京 学院大学外国語学部文京学院短期大学紀要, 10, 1-9. https://www.u-bunkyo.ac.jp/center/library/ image/fsell2010_001-009.pdf

United Nations. (n.d.). Convention on the rights of persons with disabilities and optional protocol. https://www.un.org/disabilities/documents/convention/convoptprot-e.pdf
Watanabe, M., Suzuki, Y., \& Takahashi, S. (2017). Rethinking the history of inclusive education in Japan: Focusing on the movement towards inclusive education in the 1970s. Working Paper Series in Young Scholar Training Program, 13, 1-10. https://www.schoolexcellence.p.u-tokyo.ac.jp/cms/ wp-content/uploads/2017/07/Y-WP13.pdf 